\title{
Blended learning with Edmodo: The effectiveness of statistical learning during the COVID-19 pandemic
}

\author{
Rini Sefriani, Rina Sepriana, Indra Wijaya, Popi Radyuli, Menrisal \\ Department of Informatics Engineering Education, Universitas Putra Indonesia YPTK, Indonesia
}

\begin{tabular}{l} 
Article Info \\
\hline Article history: \\
Received Jul 3, 2020 \\
Revised Dec 19, 2020 \\
Accepted Jan 25, 2021 \\
\hline
\end{tabular}

\section{Keywords:}

Blended learning

COVID-19

Edmodo

Virtual learning

\begin{abstract}
The condition of all countries in the world is devastated by the presence of a corona virus epidemic known as Corona Virus Diseases-19 (COVID-19). The efforts of the Indonesian government to break the chain of distribution of COVID-19 in the midst of society is to impose a policy of keeping distance, avoiding publicity, frequent hand washing and wearing masks. This also has an impact on the field of education where learning from home is also known as work from home (WFH). Learning is done with an online learning system that at least applies distance, physical social protection. Blended learning is one that is done using the Edmodo application, which can be done online at home. The purpose of this study is to find out how effective the use of the blended-learning learning model with Edmodo applications is to students of Informatics Engineering Education during the COVID-19 pandemic. This research is a quasi-experimental design with a pre-test and post-test control group. The results of this study indicate that the use of Edmodo's blendedlearning learning model in Information Technology Education students during the COVID-19 pandemic period is effective and can be used as a virtual learning solution.
\end{abstract}

This is an open access article under the CC BY-SA license.

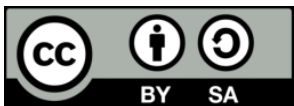

\section{Corresponding Author:}

Rini Sefriani

Department of Informatics Engineering Education

Universitas Putra Indonesia YPTK

Jl. Raya Lubuk Begalung Padang, Sumatera Barat, Indonesia

Email: rinisefriani@upiyptk.ac.id

\section{INTRODUCTION}

Since the end of 2019 the world has been stirred by the emergence of viruses that have caused many human deaths, so it becomes a global problem. The initial appearance occurred in China precisely in the Wuhan area. As long as the COVID-19 outbreak is still ongoing and there are no signs of its spread decreasing, the Indonesian government has adopted a policy of keeping social distance keeping physical distance, washing hands frequently, wearing masks when dealing outside of the home and implementing new rules that are all activities done at home using an online system. Online activities are also applied to the world of education. There is no exception to learning done by universities because it is influenced by the COVID-19 epidemic [1]. Online learning activities are implemented at the tertiary level with the expectation that students continue to learn and hone academic and non-academic skills and improve digital literacy [2]. Online learning demands the creative work of educators, so students still get the right education despite the limited space.

Innovation and creativity of teachers in presenting and delivering learning materials and learning activities [3,4] continue to support the development and stimulate student intelligence. Like giving assignments in accordance with the learning theme that was originally designed. This has become one of the 
positive effects of technological progress, so that it becomes a solution and an alternative for educators in dealing with the COVID-19 outbreak during this pandemic. Blended learning by using an application or learning management system (LMS) platform makes students smarter in using their smartphones [2] this can help students to become more aware of technology, so as to be able to improve their digital literacy abilities. The availability of various types of LMS application/platforms greatly helps educators in developing and combining the application of learning models. Among the available applications are Edmodo, schoology, google classroom, google form and others. The rapid increase in communication and data innovation has changed the model and design of learning in the world of education. The right learning model in this pandemic is blended-learning [5].

Utilization of Edmodo as an instrument used for the delivery of learning online [5]. Allan said that blended learning is the use of various internet-based tools including chat rooms, discussion groups, podcasts, and self-assessment tools to support traditional [6]. Mirza, et al. [7] believes that blended learning is learning that combines classroom learning activities face to face with online learning activities and shows that there is an acceleration in improving human skills and knowledge. While, Rusman states that blended learning is a combination or combination of face-to-face learning and electronic learning or e-learning [8]. According to the USA Information Management Management Association blended learning is a learning mode that offers an online mix (through digital media/online) and face-to-face delivery and teaching. Thus the common thread of understanding blended learning can be drawn that is the combination of face-to-face learning with online learning (in the network) or online.

Edmodo is one application that has been widely used by the world of education in the learning process. Edmodo is a social learning platform for teachers/lecturers, students/students and parents/guardians which was developed in late 2008 [9]. Edmodo is designed to make students eager to study in the more familiar environment of [10]. Edmodo is a learning management system that is open source and can be accessed free of charge by anyone Edmodo can be developed by users according to their needs. The use of Edmodo is very user friendly and anyone can easily use this application, without having to take courses or tutorials that take a long time. Edmodo has complete features to assist in the online learning process, which is equippedwith home, classroom settings, library, discover, and message. Edmodo can not only be used in the world of formal education, but private organizations, governments can also use it. Because the administration and security management owned by Edmodo is quite good. By using Edmodo, it helps the teacher in giving assignments and learning material, because it is equipped with a place of assignment which is a place for collecting tasks, doing quizzes for students. The advantage of this Edmodo is the control link for parents can monitor student learning activities, and various other activities carried out online [4].

Blended learning with Edmodo has actually done a lot of research studies by previous researchers. Edmodo was the right choice to use as an online learning media for lecturers and students. Edmodo application allows lectures to be conducted in mobile learning with unlimited space and time [10]. Edmodo can be used as a medium for learning mathematics in providing material, assignments and projects to students that can be monitored without having to be in the lecture hall [10]. Nurhayati [11] based on the research she had done said that from the research results it was known that Edmodo was effectively used as a learning medium and could improve student learning outcomes so that it could be concluded that the use of Edmodo learning media was more effective than using conventional learning models. In line with previous research, Wijaya also revealed that Edmodo-assisted learning has an influence on student learning outcomes. Radyuli, et al. [12] in his research with the blended learning model using the Google Form LMS platform also stated that it has a positive impact on student learning outcomes after they learn on a Google form-based basis. Based on research conducted by these researchers, it can be concluded that the use of LMS applications in this case Edmodo has a positive influence on learning. Edmodo's website address can be visited to https://new.edmodo.com [13].

Learning by using applications that are already available free of charge such as Edmodo, has been widely used by educators, there are also some studies that use applications designed by researchers themselves and then see the impact on learning. Among them, Wijaya who developed and made interactive multimedia in learning as a supplement for teachers and students [14]. The same thing was done by Sefriani, by creating an interactive module with the aim of helping students and teachers in learning [15]. Android-based modules are also widely made by researchers with the aim of producing applications so that in learning [16]. Jafnihirda, et al. [17] developed learning media applications as a supplement in improving learning outcomes. Andini [18] also argued that the presence of multimedia products in learning makes learning outcomes superior. Kariman, et al. [19] stated in his research that students who were taught with the help of modules increased their learning outcomes. It can be concluded that instructional media produced in the form of applications or actual teaching media as a means for educators to combine learning models applied in class. The learning model can be in the form of blended learning with the help of interactive multimedia, applications and interactive modules in other forms. Because with the LMS application and interactive 
modules made by researchers themselves can share knowledge through various types of activities that can be monitored, such as forums and chat. So, it can be concluded that this Edmodo media can improve learning outcomes and help students understand the lesson. Based on relevant research, this research is directed at the effectiveness of using blended learning with Edmodo during the COVID-19 virus pandemic. It is hoped that this research cancontribute as well as solutions in the use of blended learning with Edmodo. Al-Said stated that students have positive perceptions [20]. Use of the moodle blended-learning learning model in Elementary School Teacher Education studentsduring the COVID-19 pandemic period is effective and can be used as a network-based learningsolution or online. Rachmadtullah, et al. [21] has proven in research that the use of the moodle blended-learning learning model in primary school teacher education students during the COVID-19 pandemic period is effective and can be used as a network-based learning solution or online.

\section{RESEARCH METHOD}

\subsection{Research design}

This type of research is quasy experimental research, with the design of a pre-test and post-test control group. The purpose of this study is to reveal how effective the use of the blended learning model using the Edmodo application is to students majoring in Informatics Engineering in statistical courses during the COVID-19 pandemic. Two groups were chosen at random by giving different learning models in each class. Pre-test and post-test were given to both groups in order to find out the difference between the pre-test and post-test results between the control class and the experimental class. The experimental class was implemented using a blended learning model using Edmodo, while the control class was using a WhatsApp group. Then, the results of the pre-test and post-test in each class are compared so that the differences between the two are obtained.

\subsection{Research subject}

The subjects of this study were students of Informatics Engineering Education who were enrolled in statistical lectures in the ongoing semester who used blended learning and WhatsApp groups in learning activities. The sampling technique in this study uses a purposive sampling technique that is the sampling technique with certain considerations. The reason for using purposive sampling technique in this study is because it requires two homogeneous classes in terms of their ability to represent population characteristics. The sample chosen was 40 students.

Figure 1 presented learning activities using the Edmodo application, while learning with WhatsApp group is shown in Figure 2. It can be seen in Figure 1 that there is a place for students to submit assignments and we can see directly the number of students who have submitted assignments to the Edmodo application system, while learning using WhatsApp group only posts material.

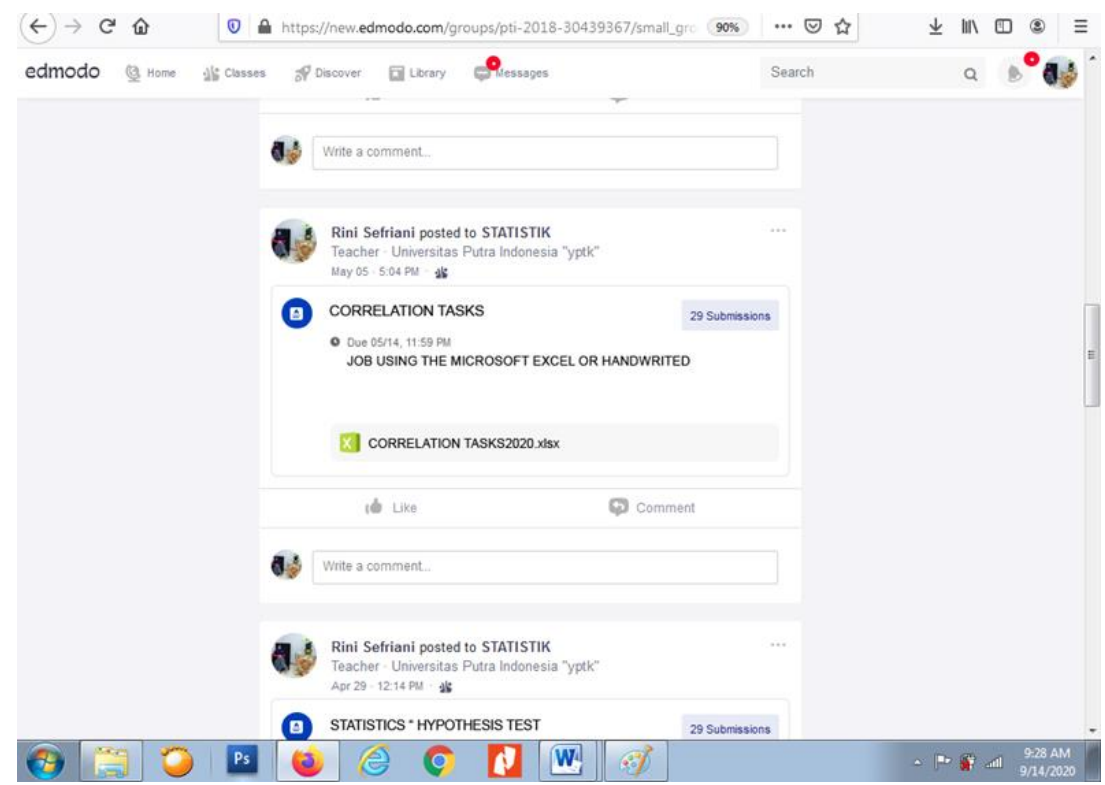

Figure 1. Display of students who have submitted assignments through Edmodo 


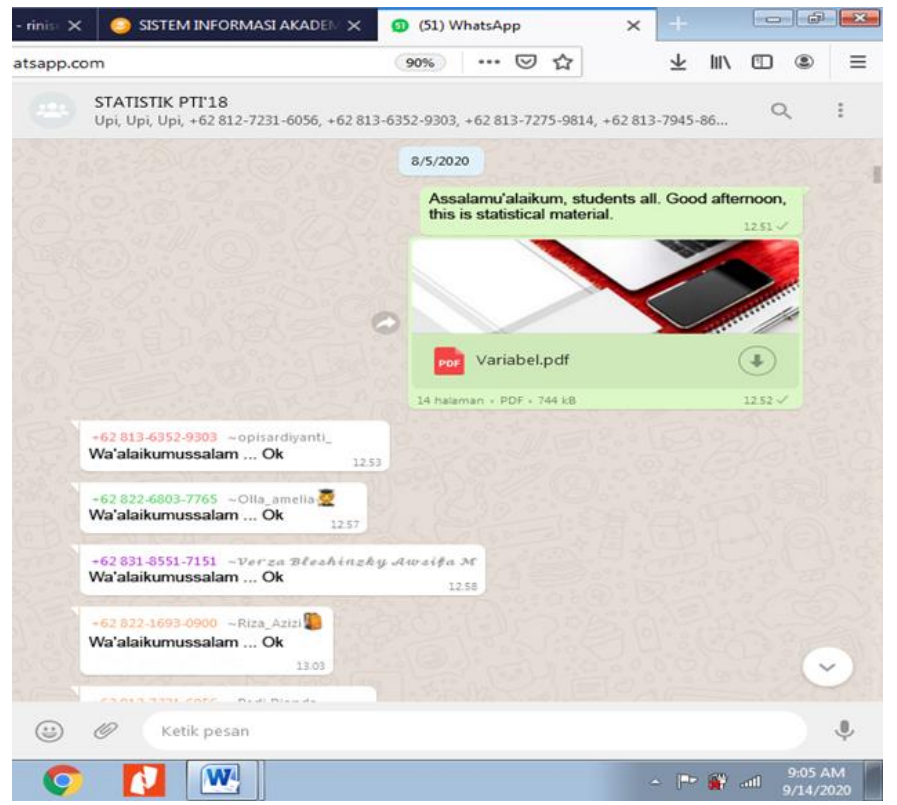

Figure 2. Learning with WhatsApp group

\subsection{Data analysis}

Data collection techniques in this study were to provide pre-test and post-test treatment. Pre-test is used to measure the initial ability of students before learning begins and post-test is used to measure the ability of students after learning to use blended learning with complete Edmodo applications. These pre-test and post-test are given to the control class and the experimental class. Then, the average difference test on the initial achievements of each experimental group was carried out. This test was conducted to determine whether there are differences in the average value for the initial achievement of the two groups. The test used was an independent sample t-test with an alpha significance level of 0.05 using SPSS 23.00 software.

\section{RESULTS AND DISCUSSION}

The results of the analysis in this study were to reveal how effective the use of blended learning using Edmodo in Informatics Engineering students during the COVID-19 pandemic. These results can be seen in Table 1.

Table 1. Paired samples statistics

\begin{tabular}{ccccc}
\hline & & $\mathrm{N}$ & Std. deviation & Std. error mean \\
\hline Pre-test & 50.7750 & 40 & 16.38086 & 2.59004 \\
Post-test & 68.9000 & 40 & 13.05766 & 2.06460 \\
\hline
\end{tabular}

Based on Table, 1 it can be seen that the average value before using blended learning with Edmodo is 50.77 and after applying blended learning treatment with Edmodo has increased by an average of 68.9. Based on these results, we can see that there is an increase in the average statistical value obtained by students. The difference in mean before and after applying blended learning with Edmodo during the COVID-19 pandemic period. Figure 3 displays the comparison between the average value of pre-test and post-test.

In Table 2, it can be seen the correlation coefficient in the pre-test and post-test groups for the analysis of blended learning models with Edmodo in informatics engineering education students during the covid-19 pandemic obtained with sig, or $p$-value $=0.000<0.005$ which means significant. Thus, blended learning with Edmodo can improve student learning outcomes in Informatics Engineering Education. Blended learning is actually one way that can improve pedagogy [22]. This is also closely related to what was conveyed by Valiathan that blended learning that combines learning by using and utilizing the internet 
has a correlation in increasing the ability of participant's students [23]. Meanwhile, research conducted by Hamka and Effendi [24] showed that blended learning with Edmodo can be used as a learning medium for delivering basic physics material. Based on this description it can be seen that, blended learning can be used as a smart solution in learning. This is closely related to the current conditions in the period during the COVID-19 pandemic where online learning is needed, with one solution being blended learning with Edmodo. Research on Blended learning with Edmodo has been done by many previous researchers, Wichadee [25] in his research stated that the implementation of Edmodo encourages educators to see how technology can facilitate learning and help students produce better academic performance. According to Dewi [26], the results showed that students had a positive impression of using Edmodo and felt comfortable interacting online with friends and teachers, so based on previous research, blended learning using Edmodo was a smart solution in learning during the COVID-19 pandemic. Opportunities that integrate innovation and the benefits of technology in online learning with the interaction and participation of the benefits of face-toface learning [27].

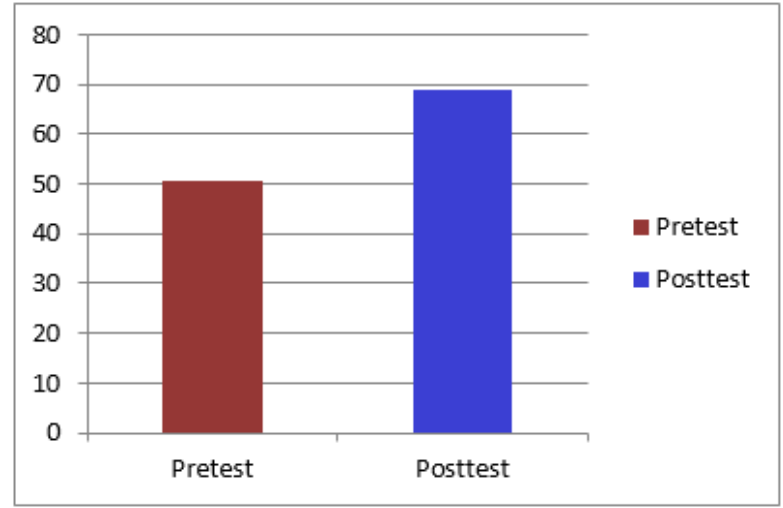

Figure 3. Differences in the mean scores of pre-test and post-test

Table 2. Paired samples correlations

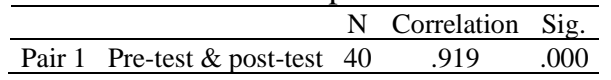

Figure 4 shows that the percentage of students doing assignments is $72.50 \%$. So, it can be said that students are very enthusiastic about learning using Edmodo. This has an impact on the improvement of student learning outcomes. This is supported by research that has been done by Ekici [28] saying that Edmodo can be used to create online practice communities in teacher education program. Hashim, et al. [29] states that the results of this study indicate that their level of literacy, readiness and awareness in using Edmodo in learning is at a high level. The positive results of this study indicate that Edmodo can be used to achieve learning outcomes for this subject, especially at the tertiary level. There are no literacy, readiness and awareness issues raised by this group of students; therefore, more activities should be mixed into the learning process and aim for positive effects. The results showed that social media, Moodle and Edmodo learning management system are beneficial for the achievement of learning objectives [30]. Improved learning outcomes using the Edmodo application are also supported by research from research conducted by Wibowo and Astriawati [31] the results of this study indicated that: 1) There is a significant increase in learning outcomes for cadets who are taught using Edmodo-based e-learning compared to those taught using face-toface learning conventional with a post-test score of 92.89 for the experimental class and 78.35 for the control class; and 2) The use of Edmodo-based e-learning in the Applied Mechanics course is considered quite effective because the n-gain test score reaches $75.82 \%$ for the class experiment. Because the use of Edmodobased e-learning has a very positive impact on improving student learning outcomes. Thus, it can be said that this application is feasible to support the learning process. In research conducted by Ali, et al. [32] found an increase in students specifically, such as; the mean score of students in the pre-test session was 68.75, the first post-test session 76.2, and the second post-test session 84.20. These results encourage students to integrate Edmodo as advanced technology in online media for every lesson, so that students become active, creative in improving skills and knowledge. Thus, it is very useful to use the Edmodo application in online learning, especially with the conditions of the COVID-19 pandemic [32]. 


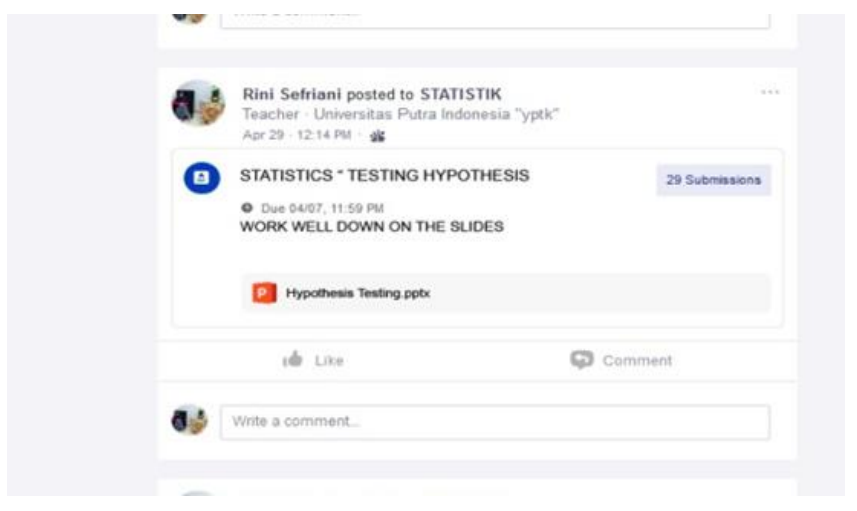

Figure 4. Students working on assignments

\section{CONCLUSION}

The findings in this study indicate that students are very enthusiastic and enjoy learning statistics with blended learning using Edmodo. Blended learning with Edmodo forces students to continue to observe its application, because learning materials and assignments are sent via Edmodo, as well as explanations of learning materials also posted on Edmodo, so as to encourage students to continue to access the Edmodo application. The time limit in collecting assignments spurred students to also collect assignments on time, because if they were late in seconds, then the task collection system in Edmodo could not be accessed anymore which meant the assignments could not be collected. Blended learning with Edmodo is a smart solution in the condition of the COVID-19 pandemic because educators and students can still do the learning even at home. Learning can be done online from each home without reducing the essence of learning itself. So that the learning objectives are achieved and the competencies expected from students are also achieved. Thus, the use of the Edmodo application in learning is an option that can be used by educators in online learning during the COVID-19 pandemic.

\section{ACKNOWLEDGEMENTS}

Thank you to the Education Study Program of the Teaching and Education Faculty, dean of the Teaching and Education faculty, Chair of the Institute of Research and Community Service at the Putra Indonesia University YPTK Padang and all parties who have contributed in this research.

\section{REFERENCES}

[1] S. P. Adhikari, et al., "Epidemiology, causes, clinical manifestation and diagnosis, prevention and control of coronavirus disease (COVID-19) during the early outbreak period: a scoping review," Infectious Diseases of Poverty, vol. 9, no. 1, pp. 1-12, 2020.

[2] R. Sefriani and R. Sepriana, "Schoology Based E-Learning Media Development in Learning Technology and Vocational Education Curriculum (in Bahasa)," Educatif: Jurnal Ilmu Pendidikan, vol. 2, no. 1, pp. 8-14, 2020.

[3] M. Nurtanto, D. Widjanarko, H. Sofyan, R. Rabiman, and M. B. Triyono, "Learning by Making Changing Automative Electrical Textual Materials into Visual Animations as Creative Learning Products (CLP)," International Journal of Scientific \& Technology Research, vol. 8, no. 10, pp. 1634-1642, 2019.

[4] N. K. R. Rabiman and M. Nurtanto, "Design and Development of E-Learning System with Learning Management Systems (LMS) in Vocaional Education," International Journal of Scientific \& Technology Research, vol. 9, no. 1, pp. 1060-1063 2020.

[5] Rasmitadila, Widyasari, M. A. Humaira, A. R. S. Tambunan, R. Rachmadtullah, and A. Samsudin, "Using a Mixed Learning Approach (BLA) in Inclusive Education Course: Studies that Investigate Teacher Students' Perceptions," International Journal of Emerging Technologies in Learning (iJET), vol. 15, no. 2, pp. 72-85, 2020.

[6] B. Allan, Blended Learning: Tools for Teaching and Training. Facet, 2007.

[7] A. S. Mirza, F. Ahmadi, L. A. Rachmawati, and N. L. Masruroh, "Digital Technology on Millenial Generation: Potere Mobile Devices on Primary Students for Supporting Learning," International Conference on Science and Education and Technology 2018 (ISET 2018), 2018, pp. 42-45.

[8] Rusman, Computer Based Learning and Learning (in Bahasa). Bandung: ALfabeta, 2012.

[9] V. Paliktzoglou, "Edmodo," in S. Danver, Ed. The SAGE encyclopedia of online education. SAGE Publications, Inc., 2016, pp. 376-377.

[10] Usman BV., "Edmodo based e-learning in teaching English in the accounting department politeknik negeri Samarinda (in Bahasa)," Jurnal EKSIS, vol. 12, no. 1, pp. 3214-3345, 2016. 
[11] D. A. W. Nurhayati, "Students' Perspective on Innovative Teaching Model Using Edmodo in Teaching English Phonology: A Virtual Class Development," Din. Ilmu, vol. 19, no. 1, pp. 13-35, 2019.

[12] P. Radyuli, R. Sefriani, and N. Qomariah, "Inquiry Learning Using Google Form on Simulation Learning Results and Digital Communication (in Bahasa)," Edukatif: Jurnal Ilmu Pendidikan, vol. 1, no. 2, pp. 56-63, 2019.

[13] "No Title," [Online]. Available: https://new.edmodo.com.

[14] R. Sefriani and I. Wijaya, "Interactive Multimedia Learning Module Based on Adobe Director on Operation System Course on Vocational High School," Journal of Information Technology and Computer Science (INTECOMS), vol. 1, no. 1, pp. 60-71, 2018.

[15] R. Sefriani, I. Wijaya, and P. Radyuli "Development of android based learning media on the subjects of digital photo composition for vocational high school student," VOLT Jurnal Ilmiah Pendidikan Teknik Elektro, vol. 3, no. 2, 2018.

[16] R. Sefriani and J. Veri, "Development of client Server Based Mobile Learning in Digital Simulation Subjects (in Bahasa)," UPI YPTK Jurnal KomTekInfo, vol. 5, no. 3, pp. 61-71, 2019, doi: 10.29165/komtekinfo.v5i3.194.

[17] L. Jafnihirda, D. Diani, and R. Sefriani, "Development of a Professional 3D Pageflip-Based Graphic Design Learning Module (in Bahasa)," Jurnal Pendidikan Teknologi Informasi, vol. 6, no. 1, pp. 45-54, 2019.

[18] S. Andini, "Developing Flipbook Multimedia: The Achievement of Informal Deductive Thinking Level," Journal on Mathematics Education, vol. 9, no. 2, pp. 227-238, 2018.

[19] D. Kariman, Y. Harisman, A. Sovia, and R. C. I. Prahmana, "Effectiveness of Guided Discovery-Based Module: A Case Study in Padang City, Indonesia," Journal on Mathematics Education, vol. 10, no. 2, pp. 239-250, 2019.

[20] K. M. Al-Said, "Students' Perceptions of Edmodo and Mobile Learning and Their Real Barriers towards Them," The Turkish Online Journal of Educational Technology, vol. 14, no. 2, pp. 167-180, 2015.

[21] R. Rachmadtullah, et al., "Use of Blended Learning with Moodle: Study Effectiveness in Elementary School Teacher Education Students during the COVID-19 pandemic," Int. J. Advan. Sci. Techno., vol. 29, no. 7, pp. 3272-3277 2020. [Online]. Available: http://sersc.org/journals/index.php/IJAST/article/view/18956

[22] C. R. Graham, "Blended learning systems," in The Handbook of Blended Learning: Global Perspectives, Local Designs. John Wiley \& Sons, 2006, pp. 1-26.

[23] P. Valiathan, "Blended learning models," Learning Circuit, vol. 3, no. 8, pp. 50-59, 2002.

[24] D. Hamka and N. Effendi, "Development of Edmodo-Based Blended Learning Learning Media in Basic Physics Subjects in the Science Education Program (in Bahasa)," Journal of Natural Science and Integration," vol. 2, no. 1, pp. 19-33, 2019.

[25] S. Wichadee, "A development of the blended learning model using Edmodo for maximizing students' oral proficiency and motivation," International Journal of Emerging Technologies in Learning (iJET), vol. 12, no. 2, pp. 137-154, 2017.

[26] F. Dewi, "Edmodo: A social learning platform for blended learning class in higher education," Research in Education Technology, Pedagogy \& Technology, vol. 8, no. 1, pp. 1-11, 2014.

[27] N. K. Z. Arifin, M. Nurtanto, W. Warju, and R. Rabiman, "The TAWOCK Conceptual model for Content Knowledge for Professional Teaching in Vocational Education," International Journal of Evaluation and Research in Education (IJERE), vol. 9, no. 3, pp. 697-703, 2020, doi: 10.11591/ijere.v9i3.20561.

[28] D. I. Ekici, "The Use of Edmodo in Creating an Online Learning Community of Practice for Learning to Teach Science," Malaysian Online Journal of Educational Sciences, vol. 5, no. 2, pp. 91-106, 2017.

[29] S. Hashim, N. A. Al Jafri, M. E. Ismail, K. A. A. Rahman, A. Masek, and A. Ismail, "Students' Literacy, Readiness and Awareness in using Edmodo for Learning," 2019 IEEE 10th Control and System Graduate Research Colloquium (ICSGRC), Shah Alam, Malaysia, 2019, pp. 231-235, doi: 10.1109/ICSGRC.2019.8837056.

[30] W. N. T. W. Hussin, J. Harun, and N. A. Shukor, "Online tools for collaborative learning to enhance student's interaction," 2019 7th International Conference on Information and Communication Technology (ICoICT), Kuala Lumpur, Malaysia, 2019, pp. 1-5, doi: 10.1109/ICoICT.2019.8835197.

[31] W. Wibowo and N. Astriawati, "The effectiveness of using Edmodo based e-learning in the applied mechanics course,” Journal of Physics: Conference Series, vol. 1511, 2019, doi: 10.1088/1742-6596/1511/1/012121.

[32] H. Ali, D. Gojali, W. Darmalaksana, A. H. Fathonih, Sajidin, and T. Ratnasih, "The Effectiveness of Using Edmodo as Online Media on Students' Outcome in Reading Course," 2019 IEEE 5th International Conference on Wireless and Telematics (ICWT), Yogyakarta, Indonesia, 2019, pp. 1-6, doi: 10.1109/ICWT47785.2019.8978236. 